\title{
HEIDEGGER'S READINGS OF KANT: APPROPRIATION OF TIME AND SPACE THROUGH UNDERSTANDING THE HISTORICITY OF DA-SEIN AS BEING-IN-THE-WORLD
}

\author{
Syed Alam Shah ${ }^{*}$
}

\begin{abstract}
Heidegger's reading of Kant is deciphered to have illuminated his own project concerning the basic question of Ontology, Time, Space and History [Temporality, Spatiality and Historicity] embodying the novel description of Human reality in terms of Mit-Dasein and Mit-welt [Subjectivity with the public face]. Kant's Critique of Pure Reason led Heidegger develop his own project of Existential Phenomenology contrary to Husserilian Phenomenology. We will discuss the Kantian Heidegger following the two main issues: one, Heidegger appreciates Kant on his identifying and exploring the difference of ontic/ontological. Two, Kant prioritizes time over space. Heidegger would explore the subject of ontic/ontological difference in the sense that ontic knowledge is the knowledge of particular beings, whereas ontological knowledge is described as the a priori condition inferring the ontic knowledge. In this sense ontological knowledge pertains to question of being rather than beings. This is how Heidegger's Kant interpretation would differ from the Neo-Kantianism of Marburg School which argued that Critique of Pure Reason is a work of epistemology. In contrast to this position, Heidegger held that Critique is a unique work of transcendental philosophy; it is theory of ontological knowledge but not ontic knowledge. Ontic knowledge of beings must conform to Being of beings [ontological foundation]. Heidegger holds that this should be Kant's "Copernican Revolution". However, Heidegger would appropriate the Kantian notion of time in the form of temporality of Dasein. Being manifests itself on beings through Being-there [Human reality] who purely understands Being. For Heidegger, temporality of Dasein is the foundation of ontological knowledge indeed.
\end{abstract}

Keywords: Being, ontic, ontological, synthetic unity, phenomenology, subjectivity, truth, Dasein, mit-dasein, temporality, spatiality, historicity, epoch, transcendence, existential

\section{Introduction}

Heidegger's famous 1925 summer course known as History of the concept of time: Prolegomena mainly focussed the question of being [Seinfrag]. His published version of Sein und Zeit [Being and Time] embedded as what is time is primarily a Kantian account of time. In this course of discussion, Heidegger has been round the problems of Ontology, Time, Space and Historicity of Dasein, especially in relations to Kant. Heidegger would expand his own work through reading of Kant specifically on time and

\footnotetext{
* Syed Alam Shah, Ph.D. Assistant Professor, Department of Philosophy, University of Karachi
} 
space as the a priori [pre-condition] of the human experiences of Vorhendenheit [present-at-hand] in-der-welt. The phenomenology of human experience through concept-categorization would lead Heidegger's own project to work out the notion of temporality of dwelling Dasein in particular place [Ort]. This is the reason why Heidegger thinks that his critical study of Critique of Pure Reason wriggled him out of the dogmatic slumber of Transcendental Phenomenology which aimed to scrutinize the very basis [transcendental aspects of human consciousness] independent of sensible world [by the method of breakting]. This concept made Heidegger shift to Existential Phenomenology. As Heidegger holds, he "studied the Critique of Pure Reason a new and read it, as it were, against the background of Husserl's Phenomenology, the scales fell from (his) eyes; and Kant became for (him) an essential confirmation of the accuracy of the path which (he) took in (his) research." (GA 25 p.431)

It was so much significant for Heidegger to read Kant Phenomenological especially on the Critique of Pure Reason that he thought, it could help advance his early project of Being and Time. Following this, we see there are two main problems which need to be examined through Heidegger's reading of Kant's Critique of Pure Reason.

1. Kant is known to have fully acknowledged the difference between Ontic and Ontological.

2. Kant recognizes the categories of time and space in terms of a priori intuitions. However, he privileges time over the space in his Critique of Pure Reason. It means space is founded on the time category which both blend together to make human experiences of the objects possible in the world.

However, the former point depicts how human knowledge of particular objects is possible. Heidegger calls this an ontic knowledge because Dasein knows beings in particular. Thus, for Heidegger, ontic knowledge is the knowledge of particular beings present-at-hand [Seindes Vorhendenheit]. Later point deals with ontological knowledge pertaining to the condition for what is known about the particular beings. As an a priori condition of the ontic knowledge [particular beings], the ontological knowledge pertains to the question of meaning and Truth of Being rather than of beings. Ontological knowledge is knowledge of Being which presences itself to the beings by concealing/revealing process. Thus, ontological knowledge is the precondition of the possibility of ontic knowledge as such. Ontic knowledge can qualify itself on the basis of ontological knowledge. Early Heidegger primarily deals with question of Being rather than beings in his famous book Sein und Zeit. For Kantian Heidegger, Critique of Pure Reason is the work embedding the theory of knowledge [epistemology]. However, Heidegger comments that Critique of Pure Reason is not the theory of ontic knowledge [mere experiences of objects appearing in the world], but it is, indeed, the theory of Ontological knowledge. (Taft 1997, p.17). Heidegger believes that ontic knowledge cannot be the primordial foundation of ontological knowledge just as beings cannot be primary source of being. So, ontic knowledge of beings is possible and must confirm to the ontological foundation e.g. Being in general. This is how Heidegger thinks that there is difference between Being and beings which traditional philosophy failed to recognize. Following this realm of argument, Heidegger further holds that knowing the difference 
between Ontic/Ontological and Being/beings lead us to recognize the difference that objects conform to our knowledge rather than our knowledge conform the truth and meaning of objects, because objects are discovered as made present to our understanding of them based on meaningful discourse in advance. For Heidegger, therefrom begins Kant's Copernican revolution e.g. instead of our knowledge conforming to objects, object must conform to our knowledge.

Herein, Kant emphasizes the scrutiny of the transcendental possibility of intuition [experience], and Heidegger differs from Kant here because he examines the ontological possibility of the ontic. It implies that Heidegger may place epistemology as an ontological concern rather than a metaphysical one. He believes that ontology is the foreground of metaphysics in general. However, this presumption has manifold effects leading to set forth the basis of his thoroughgoing research through what Heidegger learned from his readings of Kant. This is how Heidegger takes certain point of reference to what Kant wrote on the antinomies in Critique. For instance, through antinomies Kant proved that speculative cosmology, theology or psychology was not materialized through perceptual cum conceptual or categorical process. While reflecting the speculative theology he proved that one cannot understand the truth of God on the basis of reason. So, human reason is unable to prove the existence of God, because God is a being and being cannot be a real [ontic] predicate. Heidegger differs from this idea of Kant in a manner that though being is not an ontic or real predicate but it is transcendental or ontological predicate. For instance, being is being possible, being necessary, or being actual. In this sense, being cannot be real or ontic predicate, rather it can be a transcendental predicate, (GA 9, p.294) such that in order to be something, it must exist first, e.g. it must first be, because Sein in general is the primordial condition/possibility for seindes in particular. Something in particular exists only because it has being and that being is being of all beings in the world. In this way Being in general is the primal condition for the possibility for being/s in particular.

Heidegger's emphasis on the difference between ontic and ontological knowledge shows his interest in discovering the meaning and truth of being of beings through Human Dasein as being-there in der welt. Whereas Heidegger takes this difference equiprimordially analogous to what Kant's projected difference between analytic a priori and synthetic a priori judgment [knowledge]. Though, Kant projected such judgments in order to neutralize the problems architecturized by Human Scepticism. Following this realm of argument, Kant schematized the synthetic a priori judgments [knowledge] to show how mathematical systems would be established in order to help science ensue by means of experiments and systematic observations of reality as such. The ethical systems and categorical imperatives would proceed from the equiprimeordial foundations of mathematical systems. For Kant, perceptions or experiences are necessary conditions for knowledge without which knowledge is not possible. However, experience is not an enough source for knowledge because the knowledge which does not illuminate from meaning of something already known [analytic knowledge] requires the synthesis of experience and reason, perception and concepts. Kant maintains: 
"Perception without concept is blind and concept without perception is empty". (CPR A50/B74). Kant believes that perception alone cannot make knowledge possible, so reason alone cannot be the basis of our knowledge. Therefore, Kant synthesizes both experience and reason to make knowledge possible. For Kant, the significant issue of Critique was not just to show the distinction of judgments into synthetic/analytic and a posteriori/a priori, it rather centrally focused on how synthetic a priori judgments were possible. This question may continue parallel to what Heidegger rearticulated throughout Sein und Ziet as to how ontological knowledge is possible. Human mind has power to schematize both reason and perceptions into synthetic unity through faculty of imagination on the basis of temporality.

For Heidegger, human Dasein is time itself, so temporality is the basic constitution of human reality in the world, and this is how human being-there has productive power to purely contemplate Being. Thus, temporality of human reality, in Heidegger's philosophy, is the primordial condition / foundation of understanding of the Being in general [ontological knowledge] (GA 25, pp.224-25). However, in his Critique of Pure Reason Kant held that temporality of human self is a basic constituent of his own-most being, and was ahistorical and transcendental. Even the early Heidegger, in his Sein und Ziet, posed Seinfrag as an ahistorical question. But, in later Heidegger this perspective on the Seinfrag and the question of Metaphysics reshuffled as an historical question. Thus, later Heidegger would consider this question as historically posed because he understands that structures of knowledge [both ontic and ontological] supposed to be absolute at a particular time are verily contingent, and need to be posed, investigated and analysed historically.

While in the same realm of reading, Heidegger changed his stance and unequivocally dissociated from the Marburg school especially in his investigating the problems of transcendental aesthetics. Heidegger disagreed with the Natorp who held that placing the Transcendental Aesthetic at the opening of Critique of Pure Reason is a well-intended mistake. Natorp thought that by placing time and space above all categories Kant seems to have suggested priority of time and space over the other concepts/categories such as quantity, quality, relations and modality. For Heidegger, Natorp intends to blur two different aspects of Critique and dissolves transcendental aesthetic into the transcendental logic altogether. Heidegger thinks that Natorp obfuscates them in order to reassess time and space in terms of categories (GA25, p.122). On the other side, Heidegger would not intend to see transcendental aesthetic disappearing into the transcendental logic. This is a reason why Heidegger would re-examine the relationships between transcendental logic/aesthetic not on the Kantian pattern, but his own. As he maintains, the issues discussed by transcendental aesthetic do not terminate into what has been elucidated through the transcendental logic. He holds: “... the Transcendental Logic takes up what the Transcendental Aesthetic deals with as a necessary foundation and a central clue. From a purely external perspective this shows itself in the fact that the time which is interpreted in the Transcendental Aesthetic in a preliminary fashion functions in all the crucial sections of the Transcendental Logic- and indeed as something fundamental”. (GA 25, p.79). 
In this extract, it is observed that Heidegger's reading of Kant shows his understanding of Critique fully mentioning ontological foundation of transcendental aesthetic. Following this, Heidegger thinks that version of time investigated in the transcendental logic is providing a reasonable background of ontological to deciphering time in the transcendental aesthetic.

Herein, Heidegger would re-schematize the transcendental aesthetic by envisaging it in terms of question of an ontological ground entrenched with his construing the problematic of synthetic a priori judgments/knowledge. By re-schematization of transcendental aesthetic, Heidegger intends to show well-known ontological question in order to enable the disclosure of a priori [Truth of Being] e.g. presencing of Being beyond the beings in terms of revealing/concealing process. In other words, the task of transcendental aesthetic is to clarify the Seinfrag, and question of being of beings is proposed as the matter of a priori disclosedness through ontological appropriation of Being of beings in relations to Dasein.

Here it is intended to show that Heidegger's re-examining the problematic of synthetic a priori episteme in terms of ontological basis would significantly strengthen his own position on the question/meaning of Transcendental Aesthetic. In other words, Heidegger's critical readings of the synthetic a priori Knowledge would underpin his reinterpretation of transcendental aesthetic in a very decisive way. Because Heidegger thinks the transcendental aesthetic is the primordial condition which provides the ontological foundation underlying the clarification of question, meaning of Being [Sinn Seinfrag].In this way, transcendental aesthetic would construe the disclosure of a priori in terms of question of meaning and truth of Being.

Through the disclosure of a priori, Being of beings manifests itself via temporality of Dasein in-der-welt. As Heidegger puts it, [the task of] 'Transcendental aesthetic'" is to set forth the ontological... makes it possible "to disclose a priori" the being [Being] of beings. Taft, (1997) p. 51. Thus Heidegger believes that Dasein is the being who $d w e l l s$ in the world of discourse, has power to understand/experience the objects spatiotemporally. For Kant, space and time as two essential constituents of transcendental aesthetic, are a priori principles or preconditions of our experiences/perceptions of objects exist in the phenomenal world.

For Heidegger this way of experiencing/understanding the objects Vorhandenheit and Zuhandenheit is constituted in through the discourse [Rede]. But these experiences are embodied aspects of human Dasein to understand the meaning of beings in the world. However, the world is the dwelling place for Human Dasein [Being-there] and its Insein [being-in]. Dwelling Dasein is temporality itself and time is the inner constituent of it. Since world is the exterior constituent of spatial Dasein thrown in the world. Space and time, in Kantian terms, are horizon of our experiencing / understanding of the objects, and we encounter things all through these two a priori principles, therefore, human experiences must yield the spatio-temporal schema.

Heidegger takes the phenomenological approach to reinterpret human encounter with objects via schematization of experience constituted by time and space. Here in the 
Kantian Heidegger may employ time and space as priori principles or pure intuitions constituted transcendentally. Since, he would explain the transcendental application of time and space in a twofold way. Space, Heidegger interprets Kant, is primordial constitutive for the enabling of a pure a priori knowledge with respect to objects [things] themselves [Phenomenal aspect of things]. Understanding space in this way is intended to show that space is 'transcendental'. In other words, space is transcendental because it is not real but ideal. As Heidegger maintains "...the transcendental aesthetic investigates such intuitions which, as pure intuitions, first make possible the empirical intuition of what is spatially and temporally present-at-hand [Vorhendenheit]" (GA25, pp.187-8). [The transcendental would make possible the experience of Vorhendenheit. Emphasis added].

Although Kant opens the new path of critical thinking, nevertheless he went on confined to the ideals of the modern Philosophical trends. He could not liberate his critical thinking from the avenue of Modern thought fully, and designed his philosophy in a way that remained bound to the fundamental conceptions of Modern Philosophy in certain ways. So Kantian philosophy is fundamentally rooted into Cartesianism. In contrast to Kantian position, Heidegger took the anti-Cartesian move and accentuated that the time should have been seen as a great significance in terms of now-point or series-of-now's, and space construed other than based in extension. Heidegger thinks that Kant reveals the notion of twofold metaphysics [metaphysics of morals and that of metaphysics of nature] materializing through Groundwork of the metaphysics of morals.

In Gesamausgabe (GA) 24, Heidegger presents the notion of a twofold metaphysics in terms of ontology of res cogitans and ontology of res extensa both as Cartesian. This is how Heidegger circumvents the idea of twofold metaphysics and tries to reinterpret space without being founded in extension, and that of schematizing the idea of beingthere [Dasein] irreducible to a transcendental subjectivity [isolated-individuatedsubject]. (GA20, 237ff, 322). This is the reason why main distinction between Heidegger's interpretation of Kant and Kant himself emerges on the twofold formulation of metaphysics of nature and of morals [ontology of res cogitans and res extensa]. For instance time, for Kant, is a priori particular through which we intuit. In contrast to this, Heidegger holds that temporality is the basic constitution of that which intuits (GA 25, p.368). Since time is the temporality of Dasein as being-in-the-world, Dasein is temporality of its own-most existence, or Dasein is time itself.

In the lecture series 'Concept of Time', Heidegger further exposed this idea that Dasein is not in time but is time itself. As he says: "Dasein, conceived in its most extreme possibility of being, is time itself, not in time" (McNeil, 1992, pp.13-14). And Heidegger further explains that time precisely is the a priori of the I-time originally than conceived by Kant. Although Kant's position on the priority of time over the space, in Transcendental Aesthetic, is clear from the point of view that Kant has accorded priority to Time over the space. Consequently, Time is the primordial condition to determine the spatiality of phenomenal self [as being-in-the-world] (GA24, p.206). Emphasis added. Following the same realm of reasoning, Heidegger, in Sein und Ziet maintains that temporality of being-in-the-world would emerge, and it may turns out, at the same time, ....as the specific spatiality of Dasein must be grounded in temporality". GA2, 335. 
We may see certain connection in these positions held by both Kant and Heidegger. Former maintains, in Critique, that space is the formal condition of the physical [Phenomenal]. Human experiences of what exist independent of Human self, are possible, we encounter the objects in the external world, and we perceive [encounter] things [beings] existing other than ourselves. This is how, Kant shows, one can have experience of the outer world only when he is able to encounter the beings other than his own-most being. For him, Encounter of the outside world goes only with capacity of outer intuition. This is the reason why Kant believes that space is the pure form of outer intuition which makes human experiences encountering with the outside world. Moreover, Kant would hold that in order to encounter the world out there, one must have self-introspection; one must know his own-most being experiencing the world. In order to know the is-ness of the outside world, I must be aware of my own being. So, self-awareness is the primordial condition of what I know things exist in the outer world.

However, Kant would hold that self-acquaintance should not be confused with the outer intuition as spatial. For him, self-awareness is not spatial in any way; it is rather succession of mental states/events in terms of presentations, volitions, and that of moods. This argument suggests that Kant takes very important position on time; he accords priority to time as pure form of inner intuition and as a formal condition of the psychical [mental states]. It entails that time is the a priori formal condition of all appearances. Herein, Heidegger follows Kant by suggesting that time is prior to space, as he writes: “. . time has a pre-eminence over space.” GA3, 48-9; GA25, 145ff.

Herein, Heidegger finds no immediate reason why should time have a priority over the space. He realizes the priority of time over the space peculiarly in the Transcendental aesthetic as the formal phase of Critique. Heidegger sees time as the primordial principle and has been defined by Kant as an essential aspect of transcendental e.g. ontological and problematic. Since, Heidegger takes this problematic as the point of departure to advance his own project of Being and Time. He accentuates the priority of Time in terms of temporality of Dasein, because time is not a feature of physical objects in instantaneously. The physical objects become temporal in a mediated way when represented by Dasein as being-in-the-world. It implies that physical objects are not temporal in an immediate sense because they cannot represent themselves as selfrealizing beings. This is how Heidegger thinks that perceiver is the point of intermediation of both internal and external world because internal and external world seem to depend on the temporality of perceiver. In this way, time is the precondition of experiencing the physical objects existing in the world; therefore, time has priority over space.

Though problem of the priority of time has been seen throughout early works of Heidegger, nevertheless he suggests that spatiality of Dasein as dwelling being in the world is pre-requisitely encompassed by temporality. Accordingly, temporality is the existential foundation of spatiality in the sense that Dasein's temporality is the precondition of his dwelling spatially. However, Heidegger's this position on time cannot be confused with Kantian priority of time over the space. It means these transcendental particulars are not mere source of human experiences, but it is human 
existence which makes experiences possible in the world. Moreover, we may describe this difference between Kant and Heidegger; former believes that priority of time over the space is the formal requirement for the experience of objects existing in the phenomenal world. Later believes that temporality is basic constitution of Dasein; and its dwelling-spatially is instituted through time. However, Heidegger does not mean that space is dissolved into or inferred from time deductively. Although it is conceivably true this ground has not been intrinsically seen throughout Sein und Ziet. But Heidegger has discussed in his HCT lectures the basic notions of Distantiality, proximity, region and orientation in order to the relations to what we need for time and analysis of time. Heidegger undoubtedly has clear position on the primacy of time, and he advises that time cannot be founded on space, and it should not be confused with observer's measuring the earthly movement in the space, or from the point of view of solar system as a whole. GA2, 367.

This is how Heidegger finds its Philosophical roots through the appropriation of Kantian Time. In his early writings Heidegger analyses the notion of Time a very significant and ground-breaking for his later works. In Sein und Zeit, Heidegger has analysed the basic notions of Verstehen [Understanding], Verfallen Sein [Fallen-being], Rede [Discourse], Angst [Attunement], and above all Being-towards-Death as fundamentally temporal investigations. If we go through his lecture course [1929-30] entitled 'The Basic Concepts of Metaphysics' in which Heidegger goes to inquire the notion of Attunement of boredom, this also takes departure from the analysis of time. Though, boredom is simply known in German language as Langeweile which lexically means long-while in English. Nevertheless, we may not propose here that these investigations had better been made from the spatial point of view. For it is obvious that Heidegger has perpetually focussed his notion of being-there as temporal resolute.

Moreover, in his later works Heidegger incorporates historicity of Dasein in terms of history of being. It has been observed that Dasein's situation [ort] and moment [nows] are the notions logically conjoined to understand the History of Being. In other words, the duality of situation and moment are akin to the study of History. Conversely, Heidegger's analysis of spatiality of zuhendenheit [equipment ready-to-hand] matures when departing its ways from the Cartesian notion of Spatiality. Heidegger does not support the idea of space in terms of geometric, mathematical or three-dimensionally measurable in polarized locations. For him, there should be a temporal Dasein who constitutes the life to the spatiality of equipment by experiencing and reflecting the different dimensions of their beings in form of distantiality, proximity, [near or far, close or distant].

The idea of Mitsein [being-with] permeates through Dasein's being in the world. The temporal Dasein realizes its own-most being by raising the question, meaning and seeking the truth of Being. This realization of Being is the sense of self-assertion and understanding of relational modality of Being of beings and beings and Being. In this way Dasein is ecstatically transcendental and being who is able to go beyond his ownbeing possible. The transcendental subjectivity is the manifestation of his temporality as being ones' self, and ecstatically being towards death. This is how Heidegger prioritizes 
temporality over the spatiality of Dasein. For Dasein is temporality itself, but not the spatiality as such.

Concluding Remarks: Heidegger's account of human reality is dynamic version of subjectivity as being to know itself on the basis of self-experience of its own most self all through historicity of Being-there. Dasein is a being situated in the world; time is the inner constituent of knowing oneself being in the world in relations to Being and beings [ontological and ontic]. Heidegger's account of ontic and ontological permeates through Kant's synthetic a priori judgements/knowledge. For Heidegger, Kant's Critique is fundamentally theory of ontological but not ontic knowledge. This claim would furnish Heidegger's account of Being as the ontological foundation of ontic [beings]. This is how he understands Kant's Copernican Revolution meant. Instead of Dasein's knowledge confirming to object, objects must confirm to Dasein's knowledge.

In this realm of argument, Heidegger re-examines the Kantian notion of refuting Being as predicate, he claims that Being either possible, actual or apodictic must be ontological predicate rather than ontic predicate. Being in general is presencing itself to what exists in particular. Heidegger reshuffles the notion of Being through the Kantian framework by differentiating Being from beings, and refutes the traditional problematic of Being and being as simulative. The possibility of ontological knowledge [of Being] embodies in the synthetic unity [schema] of pure dynamic faculty of imagination originally grounded in temporality. For Kant time is the inner intuition and possibility of selfknowledge and space is outer intuition; possibility of knowing the corporeal world. Former empowers subjectivity to know itself, and later relates to what exists physically. However, Heidegger appropriates the Kantian notion of time. Temporality is the essential constitution of human situated-ness. Human reality is less with powers of understanding and discourse, reason without perception is empty and perception without reason is blind, so are the reason and perception both meaningless without discourse. Language is the house of Being, and Dasein has ability to seek meaning and truth of Being through his existential mineness. This is how Heidegger reformulates the notion of human subjectivity and the understanding of Being [ontological knowledge] is itself grounded in the temporality of Dasein. And temporality of Dasein is historicity of human subjectivity as being towards itself and otherness. In Heideggerian perspective Human reality, structures of knowledge [absolute or contingent], should be understood, realized and examined or re-examined historically [within particular epochs and particular times].

\section{References}

Gardner, Sebastian. (1999) Kant and the Critique of Pure Reason, Routledge Philosophy Guide Book, by Sebastian Gardner, Routledge.

George, Vensus (2000) The Experience of Being As Goal of Human Existence: The Heideggerian Approach (Cultural Heritage and Contemporary Change. Series liib, South Asia, Vol.2) Council for Research in Values and Philosophy. Published in USA. 
Heidegger Martin. (1977) Sein und Ziet, (GA2) Translated by Edward Robinson and John Macquarrie as Being and Time, Oxford.Blackwell, 1962.

, (1977) GA (Gesamtausgabe) 25. Phenomenologische Interpretation von KantsKirtik der reinenvernunft, 1977.Translated by Pervis Emad and Kenneth Maly as Phenomenological Interpretation of Kant's Critique of Pure Reason, Bloomington: Indiana University Press, 1997.

, (1991) GA3 Kant und das Problem der Metaphysik, 1991.Translated by Taft as Kant and the Problem of Metaphysics, Bloomington: Indiana University Press, 1997.

1975 GA24 Die Grundprobleme der Phenomenologie, 1975. Translated by Alert Hofstader as The Basic Problems of Phenomenology, Bloomington: Indiana University Press, 1982.

(1976) Wegmarken, 1976. Marginal Pagination.Translated by Various as Pathmarks, edited by William McNeill, Cambridge: Cambridge University Press, 1998.

, (1979) GA20, Prolegomena zur Geschichte der Zeitbergriffs, 1979. Translated by Theodor Kisiel as History of the Concept of Time: Prolegomena, Bloomington: Indiana University Press, 1985.

, (1992) Concept of Time/Der Befriff der Zeit, English-German edition, translated by William McNeill: Oxford.

Kant, Immanuel. (1956) Kirtik der reinen Vernunft, Hamburg: Felix Meiner. 